\title{
DEVELOPMENT OF PEDAGOGICAL STAFF AS AN INTEGRAL ELEMENT OF FORMING A POSITIVE IMAGE OF AN EDUCATIONAL INSTITUTION
}

\author{
IRYNA BORYSHKEVYCH
}

\begin{abstract}
The formation of a positive image of the educational institution provides an increase in the efficiency of its activities and provides an opportunity to meet the needs of stakeholders. The main purpose of the image formation is also to increase competitive advantage, attract investment, establish and expand partnerships. The development of teaching staff is an integral part of forming a positive image of the educational institution, as employees are the main carriers of the brand. The career of educators is a complex multifaceted process, due to the unity of internal (subjective) and external (objective) factors. Internal factors include the living conditions of the future specialist, and external - the peculiarities of career growth (attitude to the profession and awareness of its importance). The desire for self-improvement and self-education are important drivers for the formation of successful careers of employees of educational institutions, ensuring the expansion of their creative potential, cognitive interests, and the formation of a creative personality. Based on the conducted research on building an effective strategy for the development of the employee of the educational institution, each teacher was asked to conduct their SWOT analysis, which allows identifying his/her strengths and weaknesses, as well as external opportunities and threats. The results of the SWOT analysis enable the employee of the educational institution to discover his / her existing potential and to be ready for possible changes in the external environment, which is changeable and fleeting. The strategy of career growth of the teacher is developed, which includes the following stages: conducting SWOT analysis; improvement of professionally important features and qualities; postgraduate education; passing advanced training courses; participation in various pedagogical forums, seminars, conferences, training; research of the advanced pedagogical experience, in particular concerning the use of innovative technologies; constant improvement of scientific and methodical work; forming your portfolio and, as a result, achieving a new level of career growth. Career development leads to a fundamentally new way of life of a teacher - creative self-realization in the profession, which allows identifying their individual and professional capabilities.
\end{abstract}

Keywords: image, development, career, strategy, educational institution, portfolio.

JEL Classification: I21, J24, M12, O15. 


\section{INTRODUCTION}

Problems of the image of educational institutions in scientific and theoretical terms have always attracted a lot of attention and were very relevant. The need to form the image of the institution, the introduction of innovative methods and approaches, improving their prestige due to the changing educational role in modern society, and on the other hand, the fact that society's attitude to influence the functioning of educational institutions and determines not only the level and quality of educational services but also the development of the country in different contexts: national and global. The image and reputation of its pedagogical employees play an important role in shaping the image of an educational institution. That is why considerable attention should be paid to the development of teaching staff.

In the modern educational space, the process of professional career planning has acquired qualitatively new characteristics and significantly expanded the time limits. It should also be noted that on the one hand, the appeal of modern education to the individual, the search for innovative conditions for professional self-realization, and on the other hand, socio-economic transformations in the country, clearly exacerbated the public need to form a life plan of personality, build a career development strategy for improving the quality of educational services, the use of modern interactive teaching methods and continuous improvement and accumulation of knowledge of the modern teacher.

At the forefront in the socio-economic sphere of the individual is their advancement in the ranks of status, professional, job hierarchy, and increase competitiveness. The main factor of success is the achievement of a high position in society, as a result of a purposeful professional career, which in turn affects the content of the teacher's activity.

\section{Literature ReVieW, Generalization OF MAin Statements}

The image of the organization is often understood as a certain vision in the minds of stakeholders [1]. The image must be carefully planned and subject to control. Image formation is a continuous process, as it requires conscious, systematic, and long-term action [2]. The basis of organizational image is a concept based on organizational communication, corporate communication, organization, marketing and PR management [3]. The main internal factors influencing the image include conditions of employee development, working conditions and atmosphere in the workplace, internal relationships, quality of communication processes, management image, employee motivation, and others [4]. Among the factors that shape the relationship between the organization and the external environment are PR events, brand, quality of services, communication standards and stakeholder relations, media relations, advertising, etc. [5]. The image of educational institutions should be managed in the same way as the image of business organizations [6].

The influence of image on the effectiveness of the organization is studied by the following scientists: Theurer, P. Christian, A. Tumasjan, I. Welpe, and F. Lievens explore the image and reputation as components of employer branding [7], S. Zavattaro, A. Marland, J. Eshuis continue research on brand formation [8], A. Alhadid and B. Qaddomi explore the role of public relations in the image of the organization [9], E. Rho, T. Yun, K. Lee explore the importance of organizational image for functioning organizations [10], J. López, J. González, A. Calderón explore the features of corporate image and employee satisfaction with work [11].

Problems and prospects for the development of teaching staff as an integral part of forming a positive image of the educational institution are studied by various scientists, namely, A. Dachner, J. Ellingson, R. Noe, and B.Saxton explore the future of employee development [12], A. Azmy analyzes the development of employees of educational institutions [13], E. Ludvik, E. Egerová, M. Pisoňová investigate the process of assessing the image of the school [14], J. Pérez, M. Torres investigate the assessment of the organizational image of the educational institution [15]. Given the peculiarities of the image of educational institutions and the development of teaching staff, scientists offer different ways to solve existing problems. However, the issues of an integrated approach to the organization of the process 
of teacher development need additional research.

\section{Discussion}

The purpose of this article is to form a career strategy for teachers, which is an integral part of building a positive image of the educational institution.

A professional image is an important competence of every teacher, and its formation is a laborintensive process, the result of self-knowledge and self-development [16]. The formation of a professional-pedagogical image and individual style of pedagogical activity in modern society is considered a priority [17]. In our opinion, the planning of a teacher's professional career is a component of image formation and the process of understanding career plans, the basis of which is the establishment of career development goals and ways that lead to their achievement.

When working on creating a sustainable, positive image of an educational institution, it is first of all necessary to attach special importance to those components that are primarily unchanged and permanent, namely:

1) comfort in the environment of the educational institution - the creation of friendliness in the team, as well as psychological assistance, which must be provided on time to all participants in the educational process;

2) the quality of educational services - are the actions of the educational institution aimed at the development of educational training of students, the formation of their psychological functions, the development of creative thinking, the formation of interest in leading a healthy lifestyle, etc .;

3) formed a positive style of an educational institution;

4) positively formed style of the head of the educational institution and pedagogical staff. Pedagogical, managerial, and social competence of employees, as well as relevant external attributes.

Competently created positive image of the educational institution aims to solve many problems:

1) to improve the attractiveness of the educational institution - for various interested stakeholders;

2) to improve the efficiency of dissemination of public information about updated educational services;

3) to improve actions aimed at the implementation and implementation of updated educational services;

4) actions aimed at improving the level of organizational culture of the educational institution;

5) actions aimed at improving the socio-psychological microclimate in the staff of the educational institution.

Strategy is one of the important concepts of the modern era [18], which determines the effectiveness of the organization to achieve its goals [19]. The development strategy is a long-term roadmap of the organization, which allows it to achieve higher performance compared to competitors [20]. A teacher's professional career strategy is an individual program developed and implemented by them, the so-called professional plan, which corresponds to the purpose and motives of their professional career.

Professional self-education is aimed at the realization of the teacher as a person. The desire for selfimprovement and self-education are important factors in the career of a teacher, ensuring the expansion of their creative potential, cognitive interests, and the formation of a creative personality.

The following elements are important for a teacher's career growth:

1. Study and adoption of advanced pedagogical experience as a result of acquaintance with the activities of the best teachers (attendance of open classes, acquaintance with scientific works). The analysis of their professional activity gives an opportunity to better understand the patterns of the educational process, to learn to pedagogically perceive each action of the student, to find ways to resolve the causes of conflicts, and more.

2. Regular study of modern psychological and pedagogical literature, knowledge of legislation governing educational activities, constant monitoring of new innovative pedagogical methods, meeting with innovators and learning from their experience, participation in methodological associations, conferences, including international, seminars, pedagogical readings, etc. 
3. Systematic analysis of the pedagogical press, television, radio, Internet resources. They respond quickly enough to all changes that occur in the educational space and the educational process, highlight the experience of teachers-innovators, provide information about scientific and pedagogical innovations, materials of various forums, meetings, and conferences.

4. Acquaintance with the national system of education, which contains the educational wisdom of the Ukrainian people, its best scientists, the educational significance of Ukrainian folk customs, traditions, holidays, rituals, progressive traditions of Ukrainians in family education, and more.

During the process of career growth and self-realization, the teacher must feel the freedom of selfexpression. The teacher's activity cannot be squeezed into the framework of instructions and regulated in some way. A teacher who has the freedom of self-expression can manage their development, directs their creative forces in finding innovative ways and approaches to teaching and educating students.

To develop the strategy and tactics of a teacher's career growth, it is necessary to conduct a SWOT analysis of oneself to determine one's strengths and weaknesses, existing opportunities, and threats to development. By conducting a personal SWOT analysis, a person will be able to see how they can use their strengths to realize existing opportunities and eliminate potential threats, as well as how they can use opportunities to overcome their weaknesses, turning them into strengths [21]. The teacher needs to form an inner core of professional growth and constant self-improvement, which is the basis for achieving professionalism. An example of a SWOT analysis of the teacher is given in table 1.

\begin{tabular}{|c|c|}
\hline Strengths & ses \\
\hline $\begin{array}{l}\text { 1. Extensive professional and life experience. } \\
\text { 2. Constant improvement of the professional level. } \\
\text { 3. Availability of a master's degree with the } \\
\text { qualification of manager of an educational } \\
\text { institution. } \\
\text { 4. Readiness for innovation. } \\
\text { 5. The use of educational material of different } \\
\text { content, type, form and level of complexity. } \\
\text { 6. Use of interactive teaching methods. } \\
\text { 7. Fluency in two foreign languages. } \\
\text { 8. Continuous monitoring of the level of } \\
\text { educational achievements of students in subjects. }\end{array}$ & $\begin{array}{l}\text { 1. High workload, inability to rationally allocate } \\
\text { time. } \\
\text { 2. Lack of monitoring of one's own trajectory of } \\
\text { professional growth. } \\
\text { 3. Insufficient level of studying the possibilities of } \\
\text { using elements and tools of all educational } \\
\text { technologies. } \\
\text { 4. Interactive technologies require a significant } \\
\text { amount of time to prepare lessons, which indicates } \\
\text { a lack of knowledge in this aspect. } \\
\text { 5. Lack of publications in pedagogical periodicals } \\
\text { and scientific journals. } \\
\text { 6. Low attendance of various conferences, forums } \\
\text { and seminars for the exchange of pedagogical } \\
\text { experience. }\end{array}$ \\
\hline Opp & \\
\hline $\begin{array}{l}\text { 1. Taking advanced training courses, in particular } \\
\text { courses for educators on the free online platform } \\
\text { Prometheus and on the international platform } \\
\text { Coursera. } \\
\text { 2. Participation in various pedagogical forums, } \\
\text { seminars, trainings, master classes. } \\
\text { 3. Internships and advanced training in foreign } \\
\text { schools. } \\
\text { 4. Creating your own site with all the teaching } \\
\text { materials for more effective learning. } \\
\text { 5. Systematic participation in district } \\
\text { methodological associations. }\end{array}$ & $\begin{array}{l}\text { 1. Lack of time to take online courses. } \\
\text { 2. The presence of competition between educational } \\
\text { institutions. } \\
\text { 3. Lack of funds for continuous individual training } \\
\text { and self-development (those sources of training } \\
\text { that need funding). } \\
\text { 4. Professional exhaustion. } \\
\text { 5. Psycho-emotional burnout. } \\
\text { 6. Exacerbation of the epidemiological situation in } \\
\text { the country. }\end{array}$ \\
\hline
\end{tabular}

Tab. 1. Example of SWOT analysis of a teacher*

* Source: author's research

After conducting a SWOT analysis, the teacher will be able to build their strategy and develop a 
trajectory on the career ladder.

Each educator builds his or her career based on personal characteristics, values, and skills. Career success depends more on how right the professional choice was made and how successful the professional self-determination was.

American management specialist M. Driver identifies the following types of careers:

1) Linear career. At the very beginning of work, a person chooses a certain industry and persistently, step by step throughout his life climbs the career ladder.

2) Stable career. An educator, who has a stable career configuration, chooses the field of his activity at a young age and stays in it until the end of his working life. He improves his skills but does not seek to advance through the hierarchical ladder.

3) Spiral career. This type of career is typical for people who work enthusiastically for 5-7 years, and then, having lost interest in teaching, move on to another job and start all over again.

4) Short-term career. According to this type of career, people often change from one job to another and achieve small promotions. These are mostly unskilled and often undisciplined workers.

5) Plateau career. If a person successfully copes with his responsibilities, he is considered worthy of promotion. However, after several promotions, she reaches a level that is the limit of her competence. He continues to remain at this level until retirement.

6) Declining (descending) career. A person successfully starts his professional activity and goes on promotion several times. However, due to unforeseen circumstances, the quality level of her ability to work decreases, which in turn leads to a return to the lowest level of her career [22].

A personal professional career is an integral part of a teacher's life strategy. It is based on personal growth, substantive and successful self-improvement, associated with hard work, achieving real results, the teacher's attitude to his work as a life vocation.

After analyzing the domestic and foreign scientific literature, we have developed a strategy and tactics for career development of teachers (Fig. 1).

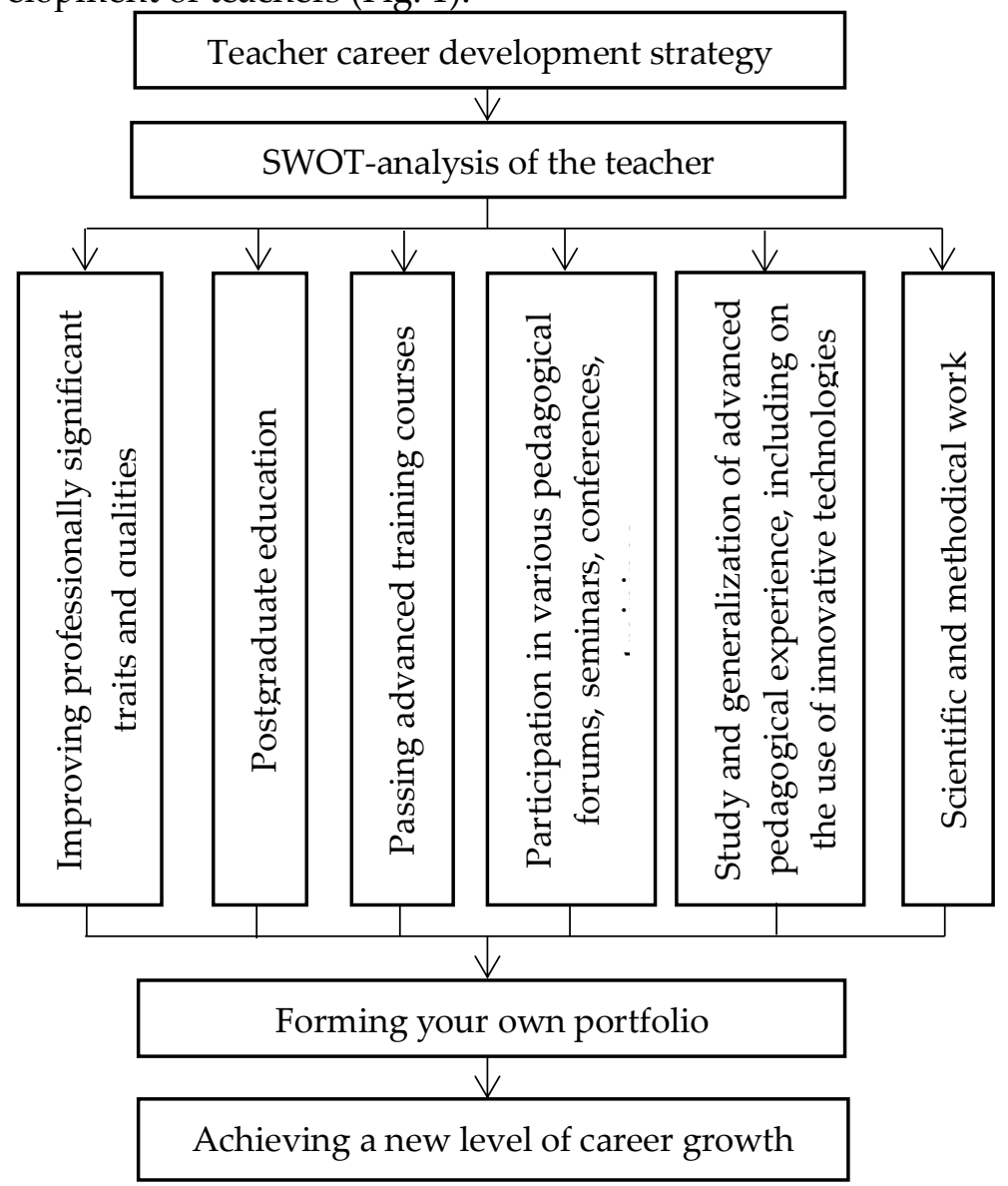

Fig. 1. Teacher career development strategy*

* Source: author's research 
Among the modern methods of professional self-improvement are the method of "portfolio", which describes the work with the analysis of its effectiveness, the most successful methodological developments, research, and articles. The portfolio may also contain documents that record professional development (diplomas, certificates, thanks, certificates, etc.), scientific, creative work, own articles, psychological research, survey results, lecture notes, educational activities. The "portfolio" method allows the teacher not only to systematize the pedagogical experience, accumulated knowledge but also to give an objective assessment of their professional level. The materials of the portfolio should be arranged according to the directions of the pedagogical activity, the chosen scientific problem, the interests of the teacher, the years of work, etc. The basis of work on the portfolio is a reflection of the professional path, views, and plans of the teacher.

The staff of an educational institution is the bearer of its brand and a component of forming a positive image. The purpose of creating a positive image is to increase competitiveness, as well as attract various investments, projects. It is mandatory to establish and expand all kinds of partnerships.

\section{ConClusions}

To bring the real image closer to the ideal, one needs to be able to manage their own development. First of all, it means to be able to take responsibility for their own lives and professional activities, to build a professional educational strategy that will take into account personal characteristics, opportunities, needs, meet the need for education, training in the chosen field, intellectual, physical, social and spiritual development. All this, in turn, involves mastering the skills of self-organization and self-regulation. Self-organization shows psychological readiness for pedagogical activity, self-regulation - conscious management of one's behavior, psyche, energy potential, control over emotions, preservation of the ability to think critically and solve complex problems.

Thus, we can conclude that the development of teaching staff plays an important role in shaping the image of the educational institution as a whole. The image of an educational institution - as a positive image, can be formed only when the end consumer is provided only quality services. The main ways of professional development are professional training, career development, and the self-education of a teacher. Career development leads to a fundamentally new way of life of a teacher - creative selfrealization in the profession, which allows identifying their individual and professional capabilities.

\section{REFERENCES}

[1] Chaturvedi S., Gupta S. Social Media - A New Tool in Modern Era Marketing. International Journal of Engineering Sciences \& Management Research, 1 (2) (2014), 80-86.

[2] Massey E., Joseph A. Theory of organizational image management. International Journal of Management and Applied Science, 2 (1) (2016), 1-6.

[3] Frandsen S. Organizational Image.The International Encyclopedia of Organizational Communication, 4 (2007), 1795-1804. doi: 10.1002/9781118955567.wbieoc103

[4] Tworzydło D. Public relations w komunikacji marketingowej. Marketing Instytucji Naukowych i Badawczych, 1 (1) (2010), 41-47.

[5] Frandsen S. Organizational Image. In Scott S., Lewis L. (Eds). The International Encyclopedia of Organizational Communication. John Wiley \& Sons, 4 (2017), 1795-1804.

[6] Jędrzejczyk W. Barriers in the Use of Social Media in Managing the Image of Educational Institutions, Procedia Computer Science, 192 (2021), 1904-1913. doi: 10.1016/j.procs.2021.08.196

[7] Theurer C.P., Tumasjan A., Welpe I.M., and Lievens F. Employer Branding: A Brand-Based Equity Review and Research Agenda, International Journal of Management Reviews, 20 (1) (2018), 155-179. doi: 10.1111/ijmr.12121 
[8] Zavattaro S.M., Marland A., Eshuis J. Public Branding and Marketing: Theoretical and Practical Developments, Public Administration Review, 81 (4) (2021), 728-730. doi: 10.1111/puar.13372

[9] Alhadid A.Y., Qaddomi B.A. The Role of Public Relations on Company Image: Social Media as a Moderating Variable: A Case Study at the Applied Science Private University at Jordan, International Journal of Academic Research in Business and Social Sciences, 6 (4) (2016), 310-317. doi: 10.6007/IJARBSS/v6i4/2109

[10]Rho E., Yun T., Lee K. Does Organizational Image Matter? Image, Identification, and Employee Behaviors in Public and Nonprofit Organizations, Public Administration Review, 75 (3) (2015), 421-431. doi: 10.1111/puar.12338

[11]J. Ivonne Hinojosa López, J. Ayup González, A. Rogelio Cogco Calderón Imagen corporativa y satisfacción laboral en potenciales empleados del sector bancario, Investigación Administrativa, 49 (1) (2020), 1-20. doi: 10.35426/IAv49n125.04

[12] Alison M. Dachner, Jill E. Ellingson, Raymond A. Noe, Brian M. Saxton The future of employee development, Human Resource Management Review, 31 (2) (2021). doi: 10.1016/j.hrmr.2019.100732

[13] Azmy A. Employee Engagement Factors in A Higher Education Institution, Binus Business Review, 10 (3) (2019). doi: 10.21512/bbr.v10i3.5857

[14]Ludvik E., Egerová E., Pisoňová M. Assessment of School Image. CEPS Journal, 8 (2) (2018), 97-122. doi: 10.26529/cepsj.546

[15]Patlán Pérez J., Martínez Torres E. Evaluation of the organizational image of a university in a higher education institutionEvaluación de la imagen organizacional universitariaen una institución de educación superior, Contaduría y Administración, 62 (1) (2017), 123-140. doi: 10.1016/j.cya.2016.01.007

[16]Zakharova S. N. Image of the teacher as a component of professional competence, Molodyi vchenyi, 1(2016), 16-18.

[17] Osadchy V., Serdyuk I. Personal site as a means of forming a digital image of a research and teaching staff. Information technologies and teaching aids, 69 (1) (2019), 78-91.

[18] Carter C. The age of strategy: strategy, organizations and society. Business History, 55 (7) (2013), 1047-1057. doi: 10.1080/00076791.2013.838030

[19]Fuertes G., Alfaro M., Vargas M., Gutierrez S., Ternero R., Sabattin J. Conceptual Framework for the Strategic Management: A Literature Review - Descriptive. Journal of Engineering, 2020 (2020). doi: $10.1155 / 2020 / 6253013$

[20]Boryshkevych I. Formulation of a Typical Development Strategy for Agricultural Enterprises (by the Method of Hoshin Kanri), Journal of Vasyl Stefanyk Precarpathian National University, 6 (3-4) (2019), 15-21. doi: doi.org/10.15330/jpnu.6.3-4.15-21

[21]Boryshkevych I., Zhuk O., Piatnychuk I. Using basic time management tools to increase personal efficiency. Efficient economy, 5 (2020). URL : http://www.economy.nayka.com.ua/?op=1\&z=7876

[22]Sundby D., Brooklyn Derr C. Michael Driver: A career life to remember, Career Development International, 12 (4) (2007), 328-340. doi: 10.1108/13620430710756735

Address: Iryna Boryshkevych, Vasyl Stefanyk Precarpathian National University, 57, Shevchenko Str, IvanoFrankivsk, 76016, Ukraine.

E-mail: iryna.boryshkevych@pnu.edu.ua.

Received: June 16, 2021; revised: August 9, 2021. 
Ірина Боришкевич. Розвиток педагогічного персоналу як невід'ємний елемент формування позитивного іміджу закладу освіти. Журнал Прикарпатського університету імені Василя Стефаника, 8 (3) (2021), 52-59.

Формування позитивного іміджу навчального закладу забезпечує підвищення ефективності його діяльності та дає можливість якнайкраще задовільнити потреби стейкхолдерів. Основною метою формування іміджу є також нарощення конкурентних переваг, залучення інвестицій, налагодження і розширення партнерських зв'язків. Розвиток педагогічного персоналу є невід'ємною складовою формування позитивного іміджу закладу освіти, оскільки працівники є основними носіями бренду. Кар'єра працівників освіти є складним багатоаспектним процесом, що зумовдюється єдністю внутрішніх (суб'єктивних) та зовнішніх (об'єктивних) факторів. До внутрішніх чинників належать умови життя майбутнього спеціаліста, а до зовнішніх - особливості кар'єрного зростання (відношення до професії та усвідомлення їі значення). Прагнення до самовдосконалення та самоосвіта є важливими рушійними чинниками до формування успішної кар'єри працівників освітніх закладів, що забезпечують розширення їх творчих можливостей, пізнавальних інтересів та формування творчої індивідуальності. На основі проведених досліджень для побудови ефективної стратегії розвитку працівника навчального закладу було запропоновано кожному педагогу здійснювати власний SWOTаналіз, що дає можливість виокремити його сильні та слабкі сторони, а також зовнішні можливості та загрози. Результати SWOT-аналізу дають можливість працівнику закладу освіти виявити свій наявний потенціал та бути готовим до можливих змін у зовнішньому середовищі, що є мінливим та швидкоплинним. Розроблено стратегію кар'єрного зростання педагога, що включає наступні етапи: проведення SWOT-аналізу; удосконалення професійно-важливих рис та якостей; здобуття післядипломної освіти; проходження курсів підвищення кваліфікації; участь у різних педагогічних форумах, семінарах, конференціях, тренінгах; дослідження передового педагогічного досвіду, зокрема щодо використання інноваційних технологій; постійне удосконалення науково-методичної роботи; формування власного портфоліо та, як результат, досягнення нового рівня кар'єрного зростання. Кар'єрний розвиток веде до принципово нового способу життєдіяльності педагога - творчої самореалізації в професії, що дає можливість виявити свої індивідуальні та професійні можливості.

Кдючові слова: імідж, розвиток, кар'єра, стратегія, освітній заклад, портфоліо. 